\title{
PERAN SISTEM INFORMASI MANAJEMEN
}

(SIM)

\section{DALAM PENGAMBILAN KEPUTUSAN}

\author{
Rafli Bima Sakti \\ Prodi Sistem Infomasi, Fakultas Sains Dan Teknologi, \\ Universitas Islam Negeri Sumatra Utara \\ Rafli.bimasakti@Gmail.com
}

\begin{abstract}
Information systems are absolutely necessary in making logical decisions so that it requires an understanding of the problem and knowledge of alternative solutions. More precise information leads to better decisions. The quality of information depends on 3 (three) things, namely, information must be accurate (accurate), timely (timesliner), and relevant (relevance).The elements in decision making that must be considered are: the purpose of decision making, identification of decision alternatives to solve the problem, calculation of factors that cannot be known beforehand or beyond the reach of humans (uncontrollable events) and the means or tools used to evaluate or measure the results of a decision making.
\end{abstract}

Keywords: Information Systems, decisions, alternatives, decision solving problems

\begin{abstract}
Abstrak
Kerangka data sangat penting dalam menentukan pilihan yang sah sehingga membutuhkan pemahaman tentang masalah dan informasi tentang pengaturan elektif. Data yang lebih tepat mendorong pilihan yang lebih baik. Sifat data bergantung pada 3 (tiga) hal, yaitu data harus tepat (tepat), ideal (garis waktu), dan dapat diterapkan (kepentingan).

Komponen dalam dinamika yang harus diperhatikan adalah: motivasi dibalik dinamika, ID pilihan pilihan untuk mengatasi masalah, penghitungan elemen yang belum dapat diketahui atau melewati rentang orang (kejadian liar) dan metode atau instrumen yang digunakan untuk menilai atau mengukur efek samping dari suatu dinamika.
\end{abstract}

Kata kunci: Kerangka Data, pilihan, ID opsi, pilihan menangani masalah 


\section{PENDAHULUAN}

Di masa sekarang ini, data dirasa menjadi kebutuhan hidup bagi semua individu, seperti sandang, pangan, dan rumah aman. Dari berbagai sudut pandang, data memiliki opsi untuk menggerakkan berbagai bidang kehidupan publik yang mencakup bidang masalah Keuangan, Sosial-Budaya, Inovasi, dan Ilmu Pengetahuan.

Dengan kemajuan ilmu pengetahuan dan inovasi data, banyak terjadi perubahan sudut pandang dan cara hidup masyarakat Indonesia dalam menyelesaikan latihannya. Kehadiran dan bagian dari inovasi data telah memperoleh periode kemajuan lain di semua bidang, namun peningkatan ini belum dikoordinasikan oleh pengembangan SDM yang menentukan pencapaian tujuan pendirian.

Data adalah segala jenis korespondensi yang memperluas pemahaman dan informasi, yang berharga bagi penerima data. Data menyerupai aliran darah di tubuh suatu asosiasi. Sumber data adalah informasi, yaitu realitas spesifik yang menggambarkan peristiwa nyata dan solidaritas sejati. Informasi adalah suatu struktur yang masih mentah yang tidak dapat diceritakan banyak, sehingga perlu dipersiapkan lebih lanjut. Informasi disiapkan melalui model untuk menyampaikan data.

Kerangka data sebenarnya merupakan sub kerangka kerja yang penting untuk kerangka kerja yang lebih besar. Kerangka data tidak dapat direncanakan dan bekerja secara mandiri dari subsistem yang berbeda.

Kerangka data hanyalah salah satu dari beberapa sub-kerangka kerja yang dimiliki oleh sebuah asosiasi. Kapasitas subsistem yang berbeda bergantung sepenuhnya pada pekerjaan asosiasi. Subsistem ini biasanya digambarkan dalam latihan dan seperti yang ditunjukkan oleh cabang asosiasi tertentu.

Bagian dari kerangka data adalah untuk membantu mengontrol dan menyusun latihan sub sistem dalam asosiasi untuk membantu asosiasi mencapai tujuannya.

Setiap individu dari asosiasi membutuhkan dan menyampaikan data sebagai aspek tanggung jawab mereka dan kerangka data akan mengatur kebutuhan setiap individu. Koordinasi ini merupakan bagian fundamental dari pendekatan kerangka kerja.

\section{STUDI LITERATUR}

Penulisan kajian yang telah saya lakukan dengan mengambil beberapa data dari buku, makalah, situs, diari, dan lain sebagainya yang tentunya membahas tentang pemeriksaan kerangka data administrasi berbasis PC secara dinamis.

\section{METODE PENELITIAN}

Artikel ini jelas merupakan dinamika eksplorasi di zaman kuno dan saat ini, di mana periode sebelumnya bersifat moderat dan membutuhkan banyak waktu dalam siklus dinamis, daripada waktu yang canggih saat ini di mana interaksi dinamika harus dimungkinkan dengan cepat. dan tidak membutuhkan banyak waktu., dengan memanfaatkan berbagai macam framework data eksekutif yang semakin berkembang pesat dan memanfaatkan inovasi PC sebagai pemegang atau 
perkantoran. Dalam strategi ini, inovasi kerangka data dewan hanya menyoroti dinamika asosiasi atau organisasi untuk mencapai tujuan khusus mereka di bidang masing-masing.

\section{PEMBAHASAN}

\section{Konsep Dasar Sistem}

Kerangka kerja adalah suatu organisasi dari siklus yang saling berhubungan, terakumulasi dan bersama-sama untuk melakukan suatu tindakan atau untuk menyelesaikan suatu tujuan tertentu. Suatu kerangka kerja terdiri dari berbagai bagian yang saling berhubungan, bekerja sama membentuk satu kesatuan. Segmen kerangka atau komponen kerangka dapat menjadi sub kerangka atau bagian dari kerangka. Setiap sub-kerangka kerja memiliki sifat kerangka kerja untuk melengkapi kapasitas tertentu dan berdampak pada ukuran kerangka kerja secara keseluruhan.

Kontak media antara satu sub framework dengan sub framework lainnya biasanya disebut kontak (interface). Melalui koneksi ini, memungkinkan aset untuk bergerak mulai dari satu sub framework lalu ke sub framework berikutnya. Melalui interfacing (hasil) untuk sub kerangka akan (masukan) sub kerangka lain. Dengan mengaitkan satu sub framework dapat berkomunikasi dengan sub framework lainnya untuk membentuk satu kesatuan.

Suatu kerangka kerja harus memiliki satu tujuan atau sasaran. Tujuan kerangka kerja benar-benar memutuskan informasi yang dibutuhkan oleh kerangka kerja dan hasil yang akan dibuat kerangka.

\section{Informasi}

Informasi yang telah dikelompokkan atau disiapkan atau diuraikan untuk digunakan dalam siklus dinamis adalah data. Kerangka penanganan mengukur informasi menjadi data atau lebih tepatnya mengukur informasi dari struktur yang tidak berguna untuk membantu penerima manfaat. Nilai data diidentifikasi dengan pilihan. Nilai data digambarkan sebagai yang paling signifikan terkait dengan pilihan. Jika tidak ada pilihan, data tidak berguna. Pilihan dapat berubah dari pilihan iteratif dasar hingga pilihan kunci jarak jauh.

Kapasitas prinsip data adalah untuk memperluas informasi atau mengurangi kerentanan klien data. Data yang diteruskan ke klien mungkin merupakan hasil dari informasi yang masuk ke dan menangani model pilihan. Meskipun demikian, dalam dinamika yang kompleks, data hanya dapat meningkatkan kemungkinan pilihan atau mengurangi bermacam-macam keputusan. Data yang diberikan kepada pemimpin memberikan faktor bahaya potensial pada berbagai tingkat gaji.

Data yang dapat ditangani atau dibuat dalam jumlah yang terlihat dari kapasitas hierarkis sangat penting karena kerangka data memberikan data formal tentang kondisi yang memberi klien tingkat kemungkinan prakiraan yang lebih menonjol dari kedua acara dan hasil dari latihan asosiasi ( menghitung latihan klien sendiri).

Hal-hal yang dapat diputuskan oleh nilai data adalah: keuntungan dan biaya perolehannya. Sebuah data dianggap penting jika keuntungannya lebih memungkinkan

dibandingkan dengan biaya mendapatkannya. Namun, harus dilihat bahwa data yang digunakan untuk beberapa tujuan membuatnya aneh dan sulit untuk menghubungkan potongan data ke 
masalah tertentu dengan biaya mendapatkannya karena sebagian besar data dinikmati dengan tidak hanya satu pertemuan dalam organisasi.

Sebagian besar data tidak dapat diuraikan sebagai keuntungan dengan insentif uang tunai, namun dapat diuraikan nilai kecukupannya. Nilai data ini bergantung pada 10 (sepuluh) kualitas, khususnya:

Sebuah. Efektif didapat Properti ini menunjukkan seberapa efektif dan cepat data dapat diperoleh. Kecepatan perolehan dapat diperkirakan, misalnya 1 momen versus 24 jam. Bagaimanapun, apa yang berharga bagi klien data sulit diukur.

b. Lapang dan lengkap

Properti ini menunjukkan total substansi data. Ini tidak hanya berarti volume, tetapi juga hasil data. Kualitas ini tidak mencolok. Itu tidak jelas dan karenanya sulit untuk diukur.

c. Ketepatan

Properti ini diidentifikasi dengan tingkat independensi dari kesalahan dalam menghasilkan data. Dibandingkan dengan volume informasi yang sangat besar, biasanya terdapat dua jenis kesalahan, yaitu kesalahan kronik spesifik dan kesalahan komputasi.

d. Kesamaan

Properti ini menunjukkan seberapa baik hasil data dapat dibandingkan dengan permintaan klien. Substansi data harus sesuai dengan masalah saat ini. Hasil yang tersisa akan sia-sia, betapapun mahal biaya pembuatannya. Atribut ini sulit diukur.

\section{e. Ketepatan waktu}

Properti ini diidentifikasi dengan waktu yang tergelincir yang lebih terbatas daripada siklus untuk memperoleh data. Informasi, persiapan, dan pengumuman hasil kepada klien umumnya mudah dilakukan. Sesekali, idealisme bisa diperkirakan.

\section{f. Jelasnya}

Properti ini menunjukkan tingkat hasil data yang dibebaskan dari istilah kabur. Memperbaiki laporan bisa jadi selangit.

\section{g. Adaptasi}

Merek dagang ini diidentifikasi dengan fleksibilitas hasil data dengan lebih dari satu pilihan, namun juga dengan lebih dari satu kepala. Properti ini sulit untuk diukur, namun dari berbagai perspektif, properti ini dapat dialokasikan dengan sangat baik.

\section{h. Terbukti}

Properti ini menunjukkan kapasitas beberapa klien data untuk menguji hasil data dan mendapatkan hasil akhir yang serupa.

I. Tidak ada bias

Merek dagang ini diidentikkan dengan kurangnya keinginan untuk mengubah data untuk mendapatkan tujuan yang telah dipikirkan sebelumnya. 


\section{j. Bisa diperkirakan}

Properti ini menunjukkan gagasan data yang dihasilkan dari kerangka data formal. Nilai dari data yang luar biasa adalah bahwa pemimpin diperbolehkan untuk memilih pilihan yang ideal untuk setiap situasi dan bukan pilihan yang pada umumnya akan ideal dan untuk menghindari kejadian yang akan membawa kemalangan. Namun, data yang luar biasa, mungkin tidak ada. Dalam kasus seperti itu, perkiraan hasil masa lalu mungkin bisa dipe dipengaruhi oleh data tambahan, meskipun data tersebut tidak memberikan jaminan, data yang cacat sebenarnya adalah data hasil pengujian (pemeriksaan). Data ini cacat karena memberikan jumlah perkiraan yang lebih besar daripada memberikan angka yang akurat.

Sifat data bergantung pada 3 (tiga) hal, yaitu data harus tepat, tepat dan relevan.

Sebuah. Tepat Data harus bebas dari kesalahan dan tidak sepihak atau menipu. Tepat juga berarti bahwa data harus mencerminkan harapan. Data harus tepat karena dari sumber data hingga penerima data kemungkinan besar akan terjadi banyak halangan (hingar-bingar) yang dapat mengubah atau memusnahkan data.

b. Sesuai jadwal

Data yang masuk ke penerima tidak boleh melewati titik tanpa pengembalian. Data yang sudah usang saat ini tidak akan dihargai karena data adalah alasan dinamika

c. Penting

Data ini memiliki manfaat bagi pemakainya. Pentingnya data mulai dari satu individu lalu ke individu berikutnya adalah unik, misalnya, data tentang penyebab kerusakan mesin kreasi untuk pembukuan organisasi kurang penting dan akan lebih signifikan jika ditujukan kepada teknisi organisasi.

\section{Sistem Informasi Manajemen (SIM)}

Kerangka Data Eksekutif (SIM) adalah organisasi data yang dibutuhkan oleh pionir dalam menjalankan kewajibannya (membantu asosiasi), terutama dalam menentukan pilihan dalam mencapai tujuan otoritatif. Strategi MIS untuk memberikan data direktur yang memberdayakan mereka untuk merencanakan dan mengendalikan aktivitas. PC telah menambahkan beberapa ukuran, seperti kecepatan, ketepatan dan volume informasi yang diperluas, yang memungkinkan pemikiran lebih banyak pilihan dalam sebuah pilihan, yang dalam sebuah asosiasi terdiri dari berbagai komponen, individu yang memiliki pekerjaan berbeda dalam asosiasi., latihan atau usaha yang harus diselesaikan, lingkungan kerja, wewenang kerja, dan hubungan korespondensi yang mengikat asosiasi. SIM adalah penggunaan kerangka data di dalam asosiasi untuk membantu data yang dibutuhkan oleh semua tingkatan dewan. Faktor yang menekan SIM adalah pada kerangka kerja, bukan pada administrasi, melainkan agar SIM dapat diselesaikan dengan baik dan cakap, itu harus diawasi sebaik yang diharapkan.

Kerangka data dalam tahapannya dapat digambarkan sebagai struktur piramida, dengan lapisan penutup data yang paling sedikit untuk penanganan pertukaran, pemeriksaan status, dll. Tahap berikut menggabungkan sumber data untuk membantu pengaturan strategis dan dinamis untuk pengawasan dan tahap atas menggabungkan data sumber untuk membantu pengaturan dan 
pembuatan strategi oleh administrasi yang lebih tinggi.

Kualitas SIM:

Sebuah. SIM bergantung pada keberadaan informasi asosiasi secara umum, dan selanjutnya bergantung pada perkembangan data yang dimiliki oleh asosiasi.

b. SIM biasanya tidak dapat membedah masalah.

c. SIM membutuhkan pengaturan yang hati-hati dan ekstensif, sementara pada saat yang sama mempertimbangkan pergantian peristiwa yang otoritatif di masa depan.

d. SIM umumnya disusun untuk informasi yang telah terjadi atau informasi yang sedang terjadi, bukan informasi yang akan terjadi.

e. SIM juga diatur untuk informasi di dalam asosiasi dibandingkan dengan informasi dari luar asosiasi.

f. SIM biasanya kuat karena banyak laporan disiapkan sebelumnya.

g. MIS membantu direktur secara terorganisir di tingkat operasional, tingkat kontrol, dan mengantisipasi staf peringkat.

h. SIM dimaksudkan untuk memberikan laporan operasional setiap hari dengan tujuan agar dapat memberikan data agar lebih siap mengontrol aktivitas.

\section{Peranan SIM dalam Pengambilan Keputusan}

Mungkin kemampuan utama dalam administrasi, khususnya dinamika, seorang pelopor lebih sering daripada tidak, pertimbangannya, dan renungannya digunakan untuk memeriksa siklus dinamis. Semakin tinggi situasi seseorang dalam hirarki administrasi, dinamika tersebut berubah menjadi tugas utama yang harus dilakukan. Tingkah laku dan metode perintis dalam teladan dinamis sangat memengaruhi tingkah laku dan mentalitas staf mereka.

Dinamika adalah konsekuensi dari pemikiran kritis, respon terhadap suatu penyelidikan sebagai hukum keadaan, dan merupakan penentuan salah satu pilihan dari pilihan lain saat ini, sama seperti penyelesaian perspektif tentang masalah atau isu yang dapat dijangkau. Efek samping dari dinamika adalah sebuah pilihan.

Dinamis memiliki dua kapasitas, untuk lebih spesifik: tahap awal dari semua latihan manusia yang sadar dan terkoordinasi, baik secara terpisah maupun dalam pertemuan, baik secara kelembagaan dan hierarki, dan sesuatu yang penting.

tajam, menyiratkan bahwa itu diidentifikasikan dengan masa depan, masa depan (dampak atau dampak bertahan dalam waktu lama).

Motivasi di balik dinamika, khususnya: tujuan tunggal, terjadi ketika pilihan berikutnya hanya menyangkut satu masalah. Artinya, setiap kali disimpulkan tidak akan ada hubungan dengan masalah yang berbeda, dan alasan ganda terjadi ketika pilihan berikutnya mencakup lebih dari satu masalah, menyiratkan bahwa pilihan diambil untuk sementara waktu untuk menangani setidaknya dua masalah, yang mana bertentangan atau tidak bertentangan.

Menurut Syamsi (1995: 13) komponen dalam dinamika yang harus diperhatikan adalah: (1) 
Sasaran dinamis, yaitu mengetahui secara spesifik terlebih dahulu destinasi yang akan dicapai dari dinamika tersebut,

(2) bukti yang dapat dikenali dari pilihan elektif untuk menangani masalah yang dipilih untuk mencapai tujuan ini. Selanjutnya, penting untuk membuat ikhtisar tentang jenis kegiatan yang memungkinkan diadakannya perlombaan, (3) perkiraan tentang faktor-faktor yang tidak dapat diketahui sebelumnya atau melewati ruang lingkup orang (kejadian liar), (4) metode atau instrumen yang digunakan untuk menilai atau mengukur konsekuensi dinamika.

Komponen dinamis yang dapat dimanfaatkan oleh inisiatif awalnya harus memiliki opsi untuk mengaudit dan mempertimbangkan target dinamis, ID masalah, variabel dalam dan luar yayasan / asosiasi, dan metode untuk dinamika.

Dinamika yang ditunjukkan oleh Terry (2002: 16) bergantung pada lima fokus yang menyertainya:

Sebuah. Naluri (perasaan)

Ketergantungan dinamis pada insting atau perasaan bersifat abstrak sehingga mudah dipengaruhi. Dinamika berbasis naluri menikmati beberapa manfaat dan rintangan. Hal-hal yang menguntungkan adalah: waktu yang digunakan untuk menentukan pilihan cukup singkat, untuk isu-isu yang memiliki dampak terbatas, dinamika akan memberikan pemenuhan sebagai suatu peraturan, kapasitas dinamis dari ketua mengambil bagian penting dan harus dimanfaatkan secara efektif. Meskipun kekurangannya meliputi: pilihan berikutnya cukup buruk, sulit untuk melacak instrumen korelasi

sehingga sulit untuk mengukur realitas dan legitimasi, berbagai esensi dinamis sering diabaikan ..

\section{b. Pengalaman}

Dinamika eksperiensial memiliki manfaat untuk informasi pragmatis karena bergantung pada pengalaman seseorang dapat mengantisipasi sesuatu dan dapat mengetahui keuntungan dan kerugian serta keuntungan dan kerugian dari pilihan berikutnya. Karena keterlibatan, seseorang dapat mengantisipasi masalah tersebut terlepas dari apakah hanya dengan melihat sekilas telah menemukan jawabannya.

\section{c. Realitas}

Ketergantungan dinamis pada realitas dapat memberikan pilihan suara, kuat dan hebat. Dengan kenyataan saat ini, tingkat kepercayaan pada kepala suku bisa lebih tinggi sehingga individu dapat mengakui pilihan yang dibuat dengan mudah dan mudah.

\section{d. Wewenang}

Ketergantungan dinamis pada kekuasaan biasanya dilakukan oleh administrasi bawahan atau individu yang posisinya lebih rendah. Dinamika berbasis otoritas juga menikmati manfaat dan bebannya. Manfaatnya antara lain: sebagian besar pengakuan adalah bawahan yang tidak terlalu memperhatikan penerima manfaat secara sengaja atau paksa, pilihan dapat berjalan cukup lama, memiliki kredibilitas (bonafid). Kekurangannya antara lain: bisa menjadikan rutinitas bersifat rutin, memadukannya dengan praktik otoriter, secara rutin melewati persoalan yang seharusnya ditangani sehingga bisa menimbulkan gejolak. 
e. Masuk akal

Pada pengambilan keputusan yang berdasarkan rasional, keputusan yang dihasilkan bersifat obyektif, logis, lebih transparan, konsisten, untuk memaksimumkan hasil atau nilai dalam batas kendala tertentu sehingga dapat dikatakan mendekati kebenaran atau sesuai dengan apa yang diinginkan. Pada pengambilan keputusan secara rasional ini terdapat beberapa hal sebagai berikut: (1) kejelasan masalah, tidak ada keraguan dan kekaburan masalah; (2) orientasi tujuan dan kesatuan pengertian tujuan yang ingin dicapai; (3) pengetahuan alternatif, seluruh alternatif diketahui jenisnya dan konsekuensinya; (4) preferensi yang jelas, alternatif bisa diurutkan sesuai kriteria; (5) hasil maksimal, pemilihan alternatif terbaik didasarkan atas hasil ekonomis yang

maksimal. Pengambilan keputusan secara rasional berlaku sepenuhnya dalam keadaan yang ideal.

\section{Jenis-jenis Pengambilan Keputusan}

Dalam dinamika yang berkepala dingin, pilihan berikutnya adalah adil, koheren, lebih lugas, dapat diprediksi, untuk menambah hasil atau kualitas dalam keharusan tertentu sehingga cenderung dianggap mendekati kenyataan atau sesuai apa yang diinginkan. Dalam dinamika normal ini, ada beberapa hal sebagai berikut: (1) kejelasan masalah, tidak ada ketidakpastian dan kekacauan masalah; (2) arah obyektif dan solidaritas dalam memahami tujuan yang ingin dicapai; (3) informasi pilihan, semua jenis dan hasil dari semua opsi diketahui; (4) kecenderungan yang jelas, pilihan dapat diatur menurut standar; (5) hasil yang paling ekstrim, penentuan opsi terbaik bergantung pada hasil keuangan

terbesar. Dinamika yang waras sepenuhnya material dalam kondisi ideal.

Macam pilihan dapat didalangi tergantung pada perspektif yang berbeda dan secara keseluruhan ada tiga macam pilihan, khususnya:

Sebuah. Pilihan tergantung pada tingkat pilihan

Ketika semua dikatakan selesai, yayasan memiliki rantai administrasi yang penting. Secara tradisional perkembangan ini diisolasi menjadi 3 tingkatan, untuk lebih spesifik: administrasi atas, administrasi pusat dan administrasi tingkat bawah.

b. Pilihan bergantung pada konsistensi

Keputu san seperti yang diungkapkan oleh Simon (1995) diisolasi menjadi 2, yaitu:

(1) dinamika yang disesuaikan: dinamika yang normal dan berlebihan melalui tindakan penanggulangan yang telah ditetapkan sebelumnya untuk mengatasi masalah melalui: metodologi (perkembangan kemajuan yang berurutan dan terkait yang harus diikuti oleh pemimpin), aturan (pengaturan yang mengawasi apa yang harus dilakukan dan pembuat strategi apa tidak boleh dilakukan), strategi (aturan yang menentukan batasan untuk memutuskan), (2) dinamika tidak terprogram: dinamika yang tidak bersifat standar dan digunakan untuk menangani masalah yang tidak terstruktur.

c. Pilihan tergantung pada iklim: pilihan ini dibagi menjadi 4 pertemuan, yaitu: (1) dinamis dalam kondisi tertentu, (2) dinamis dalam kondisi tidak aman, (3) dinamis dalam kondisi yang meragukan, (4) dinamis dalam kondisi pertikaian. 


\section{PENUTUP}

Kerangka data sangat penting untuk memenuhi kebutuhan dasar setiap hari dari semua lapisan masyarakat, baik mereka yang memiliki tingkat moneter rendah dan pendidikan hingga mereka yang memiliki tingkat keuangan dan pendidikan yang tinggi. Semakin tinggi tingkat ekonomi dan pelatihan individu, semakin tinggi kebutuhan data.

Pelaksanaan kewajiban dasar pelopor akan efektif jika didukung oleh kerangka data yang layak. Dinamika yang konsisten membutuhkan pemahaman tentang masalah dan informasi tentang pengaturan elektif. Data yang lebih tepat mendorong pilihan yang lebih baik.

Mungkin kapasitas utama dalam administrasi, khususnya dinamis. Lebih sering daripada bukan seorang pelopor, pertimbangannya, dan otaknya digunakan untuk memeriksa siklus dinamis. Semakin tinggi posisinya

Seseorang dalam administrasi hierarkis maka dinamis adalah tugas utama yang harus diselesaikan. Perilaku dan metode perintis dalam contoh dinamis sangat memengaruhi perilaku dan perspektif staf mereka.

Dinamis adalah konsekuensi dari pemikiran kritis, tanggapan terhadap penyelidikan sebagai hukum keadaan, dan merupakan penentuan salah satu opsi dari opsi lain saat ini, sama seperti akhir dari sudut pandang tentang masalah atau penutupan masalah. oleh. Konsekuensi dari dinamika adalah pilihan.

\section{DAFTAR PUSTAKA}

Husein, Fakhiri, dkk. 2002. Para eksekutif Data Frameworks. Yogyakarta: Unit Distribusi dan Percetakan AMP YKPN.

Rochaety, Eti, dkk. 2008. Sekolah Para Pelaksana Kerangka Data. Jakarta: Kemahiran Bumi

Subari, Selamat tinggal. 2005. Para eksekutif Data Frameworks. Yogyakarta: Distributer Andi

Syamsi, Ibn. 2000. Kerangka Data Dinamis. Jakarta: Kemahiran Bumi.

http://www.scribd.com./doc/butt-centric pernanan\% 20komputer-\% 20mengambil-kepUHAN.net http://katalog.library.perbanas.ac.id/download 